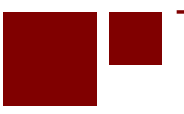

C E N T E R for RETIREMENT RE S E A R C H at BOSTON COLLEGE

\title{
JOB POLARIZATION AND LABOR MARKET OUTCOMES FOR OLDER, MIDDLE-SKILLED WORKERS
}

\author{
Matthew S. Rutledge and Qi Guan \\ CRR WP 2015-23 \\ September 2015
Center for Retirement Research at Boston College
Hovey House
140 Commonwealth Avenue
Chestnut Hill, MA 02467 \\ Tel: 617-552-1762 Fax: 617-552-0191 \\ http://crr.bc.edu
}

\begin{abstract}
Matthew S. Rutledge is a research economist at the Center for Retirement Research at Boston College (CRR). Qi Guan is a research associate at the CRR. The research reported herein was performed pursuant to a grant from the U.S. Social Security Administration (SSA) funded as part of the Retirement Research Consortium. The opinions and conclusions expressed are solely those of the authors and do not represent the opinions or policy of SSA, any agency of the federal government, or Boston College. Neither the United States Government nor any agency thereof, nor any of their employees, makes any warranty, express or implied, or assumes any legal liability or responsibility for the accuracy, completeness, or usefulness of the contents of this report. Reference herein to any specific commercial product, process or service by trade name, trademark, manufacturer, or otherwise does not necessarily constitute or imply endorsement, recommendation or favoring by the United States Government or any agency thereof. The authors thank seminar participants at the Social Security Administration for helpful comments.
\end{abstract}

(C) 2015, Matthew S. Rutledge and Qi Guan. All rights reserved. Short sections of text, not to exceed two paragraphs, may be quoted without explicit permission provided that full credit, including () notice, is given to the source. 


\begin{abstract}
About the Center for Retirement Research
The Center for Retirement Research at Boston College, part of a consortium that includes parallel centers at the University of Michigan and the National Bureau of Economic Research, was established in 1998 through a grant from the Social Security Administration. The Center's mission is to produce first-class research and forge a strong link between the academic community and decision-makers in the public and private sectors around an issue of critical importance to the nation's future. To achieve this mission, the Center sponsors a wide variety of research projects, transmits new findings to a broad audience, trains new scholars, and broadens access to valuable data sources.
\end{abstract}

Center for Retirement Research at Boston College

Hovey House

140 Commonwealth Ave

Chestnut Hill, MA 02467

Tel: 617-552-1762 Fax: 617-552-0191

http://crr.bc.edu

Affiliated Institutions:

The Brookings Institution

Massachusetts Institute of Technology

Syracuse University

Urban Institute 


\begin{abstract}
Numerous studies have found that even as employment growth in high- and low-skill occupations has been robust, employment in middle-skill occupations such as office administration and manufacturing is in long-term decline. The timing of this decline could not be worse for the older workers looking to prolong their careers to compensate for decreasing Social Security and pension income. But few existing studies have examined the consequences of job polarization on older workers, who may be less likely than prime-aged workers to find work in high- or low-skill occupations. This paper uses the Survey of Income and Program Participation to investigate employment outcomes specifically for older workers first observed in middle-skill jobs. If they leave a middle-skill job, are they able to find jobs in another skill level, or are they forced out of employment prematurely? What are the circumstances surrounding these transitions, and how are the workers' earnings affected?
\end{abstract}

This paper found that:

- Middle-skill employment among workers ages 50-61 has declined, by a magnitude that is similar to the decline among workers ages 35-49.

- But at least until the Great Recession, the probability of transitioning to a high- or lowskill job was increasing for older workers, and the share of workers ages 50-61 exiting employment was decreasing.

- While transitions from middle- to low-skill jobs may not be preferred, the fact that only half of these transitions occur after an involuntary job loss or involve switching from a full-time to a part-time work schedule suggests that these transitions may have been by choice.

- Earnings changes after skill-level transitions are modest and often positive.

The policy implications of this paper are:

- Both prime-aged and older workers have struggled to remain in middle-skill occupations but, over the long run, older workers have grown increasingly likely to land on their feet.

- Middle-skilled workers may require unemployment benefits and other income-support programs and job training to ensure that the decline in their employment opportunities does not have long-lasting consequences, but that safety net is no more necessary for older workers. 


\section{Introduction}

The divergence in wages and employment opportunities between high-skilled workers and the rest of the labor force has been well-documented. The more surprising finding is that employment opportunities are increasing for low-skilled workers as well; in the recovery from the Great Recession, in particular, low-wage jobs increased faster than middle-wage jobs (Evangelist 2014). Jaimovich and Siu (2014) report that, during the last three recessions and their jobless recoveries, nearly all of the weakness in employment growth has occurred in middle-skill jobs, while non-routine high- and low-skill jobs have grown steadily throughout the business cycle. Autor, Katz, and Kearney (2006) identify this job “polarization” as a product of technological change: automation can replace many of the routine tasks performed by middleskilled workers like administrative support staff, but high-skilled workers like engineers and low-skilled workers like custodial staff have jobs that are best done by humans.

Older workers may be particularly vulnerable to polarization; the labor market for primeaged workers was slanted more toward middle-skill occupations when these workers were younger, and it might be difficult to increase their skills up to the high level, while low-skill jobs might involve physical labor that older, middle-skilled workers are unable or unwilling to perform. This is not to say that some older workers have not benefited from the growth in highskill jobs: Tuzeman and Willis (2013) find that among workers age 55 and over employment in high-skill occupations has increased by a greater degree than for any other age group. However, unlike the substantial increase in low-skill employment at younger ages, the share of older workers in low-skill jobs has actually declined slightly, which means that middle-skilled workers unable to ascend to high-skill occupations have nowhere to go. Of further concern is that these statistics include only the employed; many older workers who are forced out of middle-skill jobs and unable to find high-skill jobs may retire early, join the growing ranks of the long-term unemployed or disabled, or otherwise drop out of the labor force (Smith 2013).

The potential consequences of a lack of middle-skill opportunities for older workers are severe, but little evidence exists that older workers have actually suffered as the result of the fall in middle-skill employment. As Social Security and defined benefit (DB) pension income decrease, older workers are extending their careers: already, the average retirement age has increased by about two years in the past two decades (Munnell 2015) and is projected to increase by approximately one more year as DB and retiree health insurance coverage continue 
to fade (Rutledge, Gillis, and Webb 2015). These projections assume that labor demand for older workers will be robust. In the recent past, this assumption may have been optimistic - and it may yet be for workers accustomed to declining routine occupations like office administration and manufacturing - but the continually rising labor force participation rates after age 50 suggests that workers are hopeful of finding work.

This project uses the Survey of Income and Program Participation (SIPP) to examine labor market outcomes for older workers by skill level. The project first examines the time trends in employment among prime-aged and older workers to determine whether the job distribution by skill level is "hollowing out" disproportionately for older individuals. The main contribution of this paper, however, is a longitudinal analysis, which compares job transitions among older and younger workers to determine whether the probability of switching skill levels has changed over time and provides more information about the nature of skill-level transitions. Most of the analysis concentrates on workers first observed in middle-skill jobs. To what extent do they move to other middle-skill jobs, or do they transition to high- or low-skill jobs? To what extent do they exit the labor force? The project uses regression analysis to determine the personal characteristics associated with each of these transitions, including education and years of experience, both overall and in the middle-skill occupation. Finally, the project examines the association between transitions across skill levels and earnings.

The results confirm earlier studies' findings that middle-skill employment is falling and that older workers are no exception to this pattern. But the rate of transition from middle-skill occupations into both high- and low-skill jobs was actually increasing until 2007, and the proportion of workers age 50-61 exiting employment was falling. The Great Recession made transitioning to other skill levels more difficult, but the fall in middle-skill employment was not as large for older workers as it was among prime-aged workers. While an increase in transitions from middle- to low-skill jobs may be concerning, descriptive information suggests that only half of these transitions occurred after an involuntary job loss, and many are associated with moving from full-time to part-time employment, which may reflect changing preferences for work among older individuals. Furthermore, earnings changes for older workers moving across skill levels are modest and, if anything, positive.

This paper is organized as follows. The first section reviews the literature on job polarization and the few papers that have examined its consequences for older workers. The 
second section describes the data and methodology, including how we separate occupations into the three skill levels. The third section reviews the cross-sectional employment patterns by age, describes the trends in the probabilities of transitioning across skill levels (or non-employment), and the circumstances surrounding those transitions, and estimates earnings losses among workers switching skill levels. The fourth section concludes that the decline in middle-skill employment has not translated to observable declines in job opportunities for older workers looking to prolong their careers.

\section{Previous Literature}

Economists as far back as Bluestone and Harrison (1988) have been aware of the disproportionate rise in low-wage employment in the late 1970s and 1980s. At the same time, and continuing into the 1990s and beyond, middle-wage employment was in decline, as documented in Juhn (1999). Juhn suggests that the growth in low-wage jobs and the coincident decline in middle-wage jobs - which use a combination of physical and cognitive skills - are consistent with a model where middle-skilled workers are a better substitute for low-skilled workers (who use purely physical skills) than for high-skilled workers (purely cognitive skills). This phenomenon - growth in low- and high-wage jobs, but declines in middle-skill jobs - was characterized as “job polarization” in Goos and Manning’s (2007) analysis of the UK labor market.

At the same time as the changes were being documented empirically, other researchers were modeling how rapid technological growth was affecting different groups of workers. In contrast to the skill-biased technological change literature that assumed that workers all fit along a single-dimensional spectrum of “skill” (Berman, Bound, and Griliches 1994), Autor, Levy, and Murnane (2003) separated workers by the types of skills they possess: the ability to do routine vs. non-routine tasks, or cognitive vs. manual tasks. Computerization has a different effect on these tasks: it complements cognitive tasks like research, complements some manual non-routine tasks in jobs like construction and agriculture, ${ }^{1}$ and substitutes for many routine tasks like filing and sorting.

\footnotetext{
${ }^{1}$ Autor (2014) draws an analogy between modern construction workers and “cyborgs” relative to historical standards, given construction workers’ use of power tools and heavy machinery.
} 
Autor, Katz, and Kearney (2006) connect these two strands of the literature: the job polarization observed in the cross-sectional employment data is likely a consequence of how workers interact with technology. The workers most vulnerable to substitution by technology are those performing routine tasks like those in office administration and manufacturing, who happen to fall in the middle of the wage distribution. In contrast, high-wage workers performing non-routine cognitive tasks have flourished as technology has made their jobs more productive. Meanwhile, low-wage workers are spared by the inability (so far) to develop technology that replaces their non-routine manual tasks. Furthermore, even where technology exists to replicate non-routine manual tasks, it may come at a cost that exceeds how much firms pay their lowwage workers already performing these tasks. ${ }^{2}$

More recent research indicates that the 2000s labor market was not as polarized - not because of low-skill employment, which continued to grow, but because high-skill employment growth faded, even before the Great Recession (Beaudry, Green, and Sand 2013; Mishel, Shierholz, and Schmitt 2013; Autor 2014). ${ }^{3}$

Most importantly, the decline in middle-skill employment continues unabated. Transitions from middle-skill employment to unemployment are especially strong in recessions, and Jaimovich and Siu (2014) find that the “jobless recoveries” experienced after the last three recessions (1990, 2001-2002, and 2007-2009) are driven almost entirely by the lack of employment growth in middle-skill jobs. Routine, manual, middle-skill jobs like construction and manufacturing have always been highly cyclical, but Foote and Ryan (2015) find that routine cognitive occupations like sales and clerical have grown increasingly sensitive to macroeconomic shocks. Manual middle-skilled workers usually find new jobs when the economy recovers, but workers tasked with routine cognitive duties are not as lucky: Foote and Ryan find that unemployed middle-skill workers rarely find work in low- or high-skill occupations, so their only options are to find another middle-skill job or exit the labor force. The resulting increase in transitions from middle-skill employment to nonparticipation explains a substantial portion of the decline in the labor force participation rate for all ages combined (Aaronson et al. 2014; Cortes et al. 2014; Foote and Ryan 2015).

\footnotetext{
${ }^{2}$ Autor (2014) adds that while routine middle-skill jobs can be outsourced to areas with lower labor costs, low-skill jobs tend to be done on-site and high-skill jobs have - so far - also been less susceptible to outsourcing.

${ }^{3}$ Foote and Ryan (2015) find that high-skill cognitive occupations have grown more cyclical over time, much like similar middle-skill jobs.
} 
Older workers are most likely to be on the margin between employment and nonemployment. Their employment prospects are increasingly subject to macroeconomic fluctuations (Munnell and Rutledge 2013). And given their short time remaining before retirement, few workers are likely to want to invest in learning skills that make them better candidates to transition to higher-skill occupations than the jobs they have had for most of their

careers. Despite these concerns, few studies of the decline in middle-skill job opportunities have focused on older workers. Autor and Dorn (2009) find that when occupations experience a decreasing level of employment in routine jobs, the average age of those occupations increases, suggesting that older workers are the ones hanging on. But Autor and Dorn use data only at the occupation or local labor market level, so they are not able to track the experience of individuals moving across occupations. Tuzeman and Willis (2013) examine the patterns of employment growth by occupational skill-level and age using individual data from the Current Population Survey (CPS) but also do not follow individuals' transitioning across occupations. Willis (2013) finds that older middle-skilled men younger than 62, and women of all ages, working in computer-intensive occupations retire at younger ages than their counterparts in jobs with less computer use but does not study transitions to other jobs.

In addition, most of the research on polarization tends to be limited to cross-sectional analysis, usually of the CPS. Only a few researchers have used longitudinal data to examine where workers go after leaving middle-skill jobs; most of these studies include an analysis by age but do not delve into the reasons that older workers would transition between skill levels or non-employment (Smith 2013; Cortes 2014; Cortes et al. 2014; Foote and Ryan 2015).

This project is the first to follow and compare middle-skilled older workers and middleskilled younger workers across occupations and from employment to non-employment and is the first to examine the association between these flows and personal characteristics.

\section{Data and Methodology}

This project uses the SIPP, a panel survey conducted by the U.S. Census Bureau that interviews each member of a household every four months for between two and five years. Separate panels start in each year from 1984 through 1993, as well as in 1996, 2001, 2004, and 2008; this study uses data from the panels begun in 1990-2008, which includes observations from the 1989-2013 calendar years. The sample is aggregated to person-years, to avoid seam 
bias (Ham, Li, and Shore-Sheppard 2009) and concentrate transitions - the monthly and by-wave transition rates are too small to characterize consistently.

We restrict the sample to individuals ages 35-61 who have ever had a job in an identifiable civilian occupation; cutting off younger workers ensures that the sample includes only prime-aged workers who have completed their education and frequent early career transitions, while stopping at age 61 ensures that all workers are not yet age-eligible for Social Security benefits. The sample further excludes the self-employed, whose labor market differs on many dimensions. Table 1 details how the sample is restricted; the final sample includes nearly 550,000 person-years, with 128,400 having worked in a middle-skill job in the previous year.

The SIPP includes information about labor market activity in each month between interview waves, including occupation, industry, hours worked, earnings, and the reasons respondents transition between jobs from one wave to the next. Periodic topical modules provide additional information; we use information from the job history module to account for how long the individual has been working in a particular occupation, and pension coverage from the retirement saving module. The respondent also provides information on demographics, family structure, total family income, health insurance coverage, and homeownership.

The analysis focuses on employment outcomes by occupational skill level. Individuals are asked about their occupation for up to two jobs at each interview wave. In each wave, we first designate the higher-paying of those jobs as the primary job. When aggregating to personyears, we keep only the primary job in the last interview wave of the calendar year, and categorize individuals by their occupation in that job, but results are similar using the occupation in that year's highest-paying job. The skill-level analysis includes a separate category for the non-employed, which is limited to individuals who are not employed throughout the last wave of the calendar year. ${ }^{4}$

Occupations are categorized by skill levels using a definition that is similar to Autor (2010), who based his classification on the wage and education composition of workers by broad Census occupational definitions. ${ }^{5}$ Autor's categorization, however, includes only 12 percent of

\footnotetext{
${ }^{4}$ We do not differentiate between those who are seeking work (the "unemployed") and those who are not seeking work (the "non-participants").

${ }^{5}$ Autor, Katz, and Kearney (2008) sort occupations by their median hourly wages in the 1980 Census, and Autor and Dorn (2009) use mean wages over 1980-2005, but subsequent studies tend to use the same not-concretelydefined categorization methods as Autor (2010). Foote and Ryan (2015) and Mishel, Shierholz, and Schmitt (2013) use Autor's classification explicitly. Tuzeman and Willis (2013) go into less detail but also seem to use the same
} 
the (unweighted) workforce in the 1990-2008 SIPP panels in the low-skill level and over half in the middle-skill category, so we modify the classification strategy to reassign some middle-skill occupations which do not involve long training periods to the low-skill level. ${ }^{6}$ Reassigning occupations such as truck drivers, bus drivers, retail sales clerks, cashiers, receptionists, typists, hotel clerks, service station employees, and machine feeders to the low skill level increases the low-skill share of employment to 24 percent and lowers the middle-skill level to 41 percent. The remaining 35 percent of jobs are classified as high-skill (Table 2).

Table 2 also reports educational attainment and earnings for each skill level. As expected, higher-skilled workers are more likely to hold a college degree or greater - 60.5 percent, compared to only 14.4 percent of middle-skilled and 7.3 percent of low-skilled workers. Low-skilled workers also have the lowest average monthly earnings (in 2013 dollars): \$2,341, compared to \$3,679 for middle- and \$5,757 for high-skilled workers.

This study first uses the SIPP cross-sectionally to establish the magnitude of the increase or decrease in employment, by skill level and separately by age and gender. This cross-sectional analysis also examines how employment growth has changed over time for each age group. ${ }^{7}$

Then, the analysis uses the SIPP longitudinally - a major contribution of this study - to examine skill-level transitions among individual workers, focusing on what happened to the workers age 50-61 observed in a middle-skill job in the prior year.

This analysis includes estimates from multinomial logit regressions, which formally test whether older workers are more or less likely to transition into 1) non-employment, 2) a low-skill job, or 3) a high-skill job, and the characteristics associated with transitions into these skill levels (or non-employment). Each outcome is relative to the base outcome of staying within the middle-skill sector (either retaining the job across years or switching to another middle-skill job).

\footnotetext{
categories. Smith (2013) uses a very similar categorization but breaks out hard-to-categorize occupations such as construction, extraction, and transportation into their own category. Holzer and Lerman (2009) use similar categories as well. Other papers, like Autor and Dorn (2013) and Beaudry, Green, and Sands (2013), further categorize occupations by the prevalence of their routine vs. manual tasks.

${ }^{6}$ In this process, we also upgrade some occupations that Autor classifies as low-skill to the middle-skill level: barbers; hairdressers and cosmetologists; police and private investigators; fire fighters and fire inspectors; and sheriffs, bailiffs, and correctional institution officers. These occupations require thorough training and often involve professional licensing, limiting the ability for low-educated job-seekers to find work in these fields.

${ }^{7}$ The cross-sectional analysis uses SIPP-provided weights to replicate population totals. The longitudinal analysis is unweighted, because the weights are not meant to be used with pooled panels. The weighted and unweighted results are similar.
} 
The independent variables of interest in the regressions are a linear time trend (or time period indicators), an indicator for age 50 or older, and the interaction of the two. A large, positive, and statistically significant marginal effect on the interaction in, for example, the nonemployment equation indicates that older middle-skill workers are disproportionately increasing their likelihood of transitioning into non-employment. ${ }^{8}$

Other explanatory variables in the regression include demographics such as gender, race, Hispanic origin, education, marital status (including spouse's age), number of children, and homeownership; compensation at the previous year's job, including earnings and indicators for health insurance, defined benefit (DB), and defined contribution (DC) pension coverage; categories of family income relative to poverty and quintiles of net worth; and duration of experience with both their current employer and in the general occupation.

Finally, the study examines the changes in earnings associated with transitions across skill levels. We estimate a linear regression among workers in middle-skill jobs in the previous year, where the dependent variable is the change in earnings between years. The key independent variables are categorical variables for transitions into low- or high-skill jobs or a different middle-skill job (relative to no job change), and the interaction of these categories with a linear time trend. The regression is estimated separately for ages 35-49 and for 50 or older. A statistically significant interaction with, for example, transitioning to a low-skill job indicates that workers see larger earnings declines now by “down-skilling” than they have in the past.

\section{Results}

\section{Trends in Employment Growth by Skill Level}

Figure 1 displays employment growth by skill level and age for 1990-2013. Each age group exhibits the polarized pattern found in previous studies, indicating that the SIPP data used cross-sectionally - produces results similar to previous studies that used CPS data. Overall, employment in middle-skill occupations decreased by 11.6 percent during the time period, while low-skill and high-skill employment increased 5.2 percent and 6.4 percent, respectively. The younger and older cohorts have experienced almost the exact same magnitudes of declines in middle-skill jobs, but older workers have seen more growth in high-skill occupations and less

\footnotetext{
${ }^{8}$ We report the marginal effects and interaction effects that account for the nonlinearity of the multinomial logit regression (Ai and Norton 2003). Standard errors are calculated by the Delta Method.
} 
growth in low-skill jobs. Among workers ages 50 and older, low-skill employment has grown by only 2.5 percent, compared to 6.2 percent at ages 35-49, but high-skill employment has grown by 9.6 percent for the older group and only 5.4 percent for the younger group.

This pattern of polarization holds up for men in both age groups and for younger women, though employment growth in the low- and high-skill levels and employment declines in the middle-skill level are larger for women 35-49 than for either group of men. The exception is older women. Employment in middle-skill jobs for women 50 and older has declined by about 15 percent, in line with younger women. But older women have seen almost no growth in lowskill occupations and a tremendous increase - 15 percent - in high-skill employment. This growth is almost certainly due to a better-educated, more-experienced cohort aging into the age 50-61 group relative to the cohort of older women they are replacing.

Figures 3a and 3b plot employment growth over time by skill level and age. Middle-skill employment is falling in each period for both age groups, but the pattern differs by age. For the younger group, the decline in middle-skill employment is progressively larger with each passing period (Figure 3b). For older workers, on the other hand, the declines are large in 1995-2000 and 2000-2007, but minuscule in 1990-1995 and 2007-2013 (Figure 3a).

Employment growth for age 50-plus in the other two skill levels also differs by period. High-skill employment growth is especially strong in 1995-2000, and low-skill employment growth among older workers is weak before 2000. ${ }^{9}$ Previous work (e.g., Beaudry, Green, and Sand 2013) has found that polarization disappears after 2000, because high-skill employment shrinks even as low-skill occupations grow robustly; our results concur at ages 35-49, but not at 50 and older - the ages where both high- and low-skill employment are increasing. Finally, in the Great Recession (2007-2013), neither low- nor high-skill older employment grows by much, but middle-skill employment at 50 and older contracts by only 0.6 percent.

\section{Transitions across Skill Levels}

While SIPP’s large sample makes it almost as conducive to cross-sectional analysis of employment trends as the CPS data used in existing studies, SIPP is better utilized

\footnotetext{
${ }^{9}$ Both the strong growth in high-skill employment in 1995-2000 and the weak growth in low-skill occupations in 1990-2000 are driven primarily by women.
} 
longitudinally. The primary analysis in this paper is on the employment outcomes in year $t$ for workers based on their skill levels in year $t-1$, focusing on workers who are middle-skilled in $t-1$.

Figure 4 plots the transition probabilities by workers' skill levels in $t-1$ for the two age groups. The height of the bar signifies the probability of transitioning away from one's skill level when first observed in the SIPP. As expected, low-skilled workers are most likely to change skill levels, especially before age 50. Otherwise, the total transition probabilities for middle- and high-skilled workers are almost equal between the two age groups, indicating that careers have stabilized by ages 35-49.

Within each bar in Figure 4, the transition probability is decomposed into the probability of exiting employment, either by “up-skilling” to a higher skill level or “down-skilling.” Exit probabilities decline as skill increases and are, unsurprisingly, higher for the older group; 6 percent of workers age 50-61 who were in a middle-skill occupation in $t-1$ are not employed for the entire last interview wave of year $t$, compared to only 4 percent of similar workers age 35-49. The higher exit probability may reflect early retirements, longer jobless spells for older job seekers (Valetta 1991), or greater incidence of disability benefit application and receipt with age.

The probability of moving to other skill levels is lower for older workers, regardless of their initial skill levels. Only 2.7 percent of middle-skilled workers move to high-skill jobs in the average year, compared to 3.5 percent of younger workers. For better or worse, middle-skilled workers are also less likely after age 50 to move to low-skill employment (3.0 percent, compared to 3.7 percent at ages 35-49). Older high-skilled workers are more secure than younger workers; their probability of moving to middle- or low-skill jobs is 4.4 percent, compared to 5.5 percent at ages 35-49. The largest job-to-job transition probability in each age group is for low-skilled workers moving to middle- or high-skill employment: 6.3 percent at ages 50-61, and 9.2 percent at ages 35-49.

The remainder of this subsection focuses on the group whose employment prospects have weakened the most over the last 25 years: workers in middle-skill employment in year $t-1$. Most middle-skilled workers remain in the same occupation and working for the same employer from one year to the next: 78 percent at ages 50-61 and 76 percent at ages 35-49 (Table 3a). Another 4 percent change employers sometime during ages 50-61, and 5 percent change during ages 3549, but they remain in the same occupation. Changing occupations is, nevertheless, fairly common: 11 percent of older middle-skill workers, and 14 percent in their prime ages, with 
about two-thirds of occupational transitions involving a change of employers. About half of the occupational transitions involve a skill-level change (Table 3b). The remaining 6 percent of older workers and 4 percent of younger workers exit employment.

Figure 5 plots the trends in destinations among workers leaving middle-skill jobs at ages 50-61 in each SIPP panel. Throughout the 1990-2013 period, though only 6 percent of older workers leave middle-skill jobs for non-employment, this share exceeds the proportion moving to another skill level. The exit probability for older, middle-skilled workers fell in the 19962004 panels, coinciding with the increase in the average retirement age (Munnell 2015). But the exit rate rose in the most recent SIPP panel to levels seen during the early 1990s, likely reflecting increased rates of job loss and disability application and receipt during the Great Recession (Munnell and Rutledge 2013).

As older, middle-skilled workers became less likely to exit employment, more of them found jobs at other skill levels. The probability of transitioning down to low-skill employment increased from about 2.7 percent, on average, in the 1990-1992 SIPP panels to almost 3.8 percent in the 2004 panel. The increase in up-skilling was even greater: from 1.5 percent in the 1990 panel to 3.7 percent in the 2004 panel. In the Great Recession, however, transition probabilities in each direction fell, though not all the way back to their early-1990s levels; 3.3 percent of older middle-skilled workers moved to a low-skill job, and the proportion moving to a high-skill occupation fell even more, to 2.8 percent in the 2008 panel. $^{10}$

Table 4 details the circumstances behind skill-level changes. Among middle-skilled workers who have transitioned to high-skill jobs, 28 percent of older workers and 36 percent of prime-aged workers are able to do so without leaving their employer. Many of these cases involve a promotion to a supervisory or managerial position: about 10 percent of middle-to-high transitions are due to a promotion within an employer, while another 20 percent of older middleto-high transitions involve changing employers to move up the ladder. Only about one-third of up-skilling workers “fall up" - that is, lose their middle-skill job involuntarily but end up in a high-skill job by the end of the following year. About equal shares of middle-to-high transitions involve moving to full time from part time or vice versa.

\footnotetext{
${ }^{10}$ Among workers ages 35-49 with middle-skill jobs in year $t-1$, the employment exit rate was roughly flat throughout the sample window, though it is lowest during the 1996 and 2004 panels that coincided with economic expansions. As with the older age group, both up-skilling and down-skilling became more common between the early-1990s and mid-2000s, and up-skilling dipped in the Great Recession. Unlike the older age group, however, down-skilling remained stable (though no longer grew) between 2001 and 2013.
} 
A surprisingly large proportion of middle-to-low-skill transitions in each age group occurs within the same employer: between 22 percent and23 percent. Down-skilling after an involuntary job loss is more common than up-skilling but occurs only about half of the time: about 49 percent of older workers and 44 percent of younger workers lose their middle-skill job involuntarily and end up in a low-skill job by the end of the following year. More middle-to-low transitions involve schedule changes than middle-to-high transitions: about 13 percent of older workers and 11 percent of prime-aged workers down-skill to move from full-time to part-time work, about double the share making the opposite schedule switch. These results suggest that moving to a lower-skill job might be a matter of choice: more than half make this transition after a voluntary job change, and both older and prime-aged workers make this change to reduce their hours, often without changing employers.

Finally, among the 6 percent of older workers who exit employment in the average year, 44 percent do so involuntarily. Since Social Security income is not yet available to these workers, we would expect to have few voluntary retirements, but just over half of employment exits are voluntary at ages 50-61. Employment exits among prime-aged workers are only a little more common: 56 percent follow an involuntary job loss.

The multinomial logit regression analysis, presented in Table 5, provides further information about the personal characteristics and economic circumstances surrounding transitions across skill levels or into non-employment. ${ }^{11}$ The estimates of the marginal effects compare the characteristics associated with the particular transition - from middle-skill to nonemployment, low-skill, or high-skill - relative to the base outcome of remaining in the middleskill level (combining both not switching occupations and switching to another middle-skill occupation).

The first three rows of Table 5 formalize the analysis of the trends in transition probabilities from Figure 5; the results are similar but mostly lacking in statistical significance once we control for other personal characteristics. The differences in transition probabilities between the two age groups are small and not statistically significant. While both middle-to-low and middle-to-high transitions have become more common for all the workers analyzed, the

\footnotetext{
${ }^{11}$ Appendix Table A1 presents means and standard deviations for workers who were in middle-skill jobs in year $t-1$, separately by their skill level (or non-employment) in year $t$, and tests the statistical significance of the difference between that skill level (or non-employment) and those workers who did not leave the middle-skill level. The results are similar to the regression analysis.
} 
negative and statistically significant interaction of the age dummy and the time trend indicates these middle-to-low transitions are generally flat for the age 50-61 group. The difference between age groups in the trend in middle-to-high transitional probability is tiny and statistically insignificant, but up-skilling is still trending upward for both age groups. ${ }^{12}$ Finally, while exits from employment have not become any more or less common for the younger group, the negative and statistically significant interaction effect indicates that older, middle-skilled workers are less likely to transition to non-employment in recent years. ${ }^{13}$

The remainder of Table 5 compares the characteristics of middle-skilled workers who remain in middle-skill occupations across years to middle-skilled workers who transition to another skill level or non-employment. Higher-earning individuals are more likely to transition to high-skill occupations, relative to staying in middle-skill jobs, and less likely to transition to low-skill jobs or exit employment. Workers with more experience in their occupations are less likely to transition to jobs at a different skill level but more likely to exit employment. Exiting employment is also more common among those with greater potential experience (age minus years of education minus 6), among workers with net worth in the top quintile, and surprisingly among workers with employer-sponsored health insurance in the middle-skill job. Women and better-educated individuals are more likely to up-skill and less likely to down-skill, and women (but not college graduates) are less likely to exit employment. Blacks are more likely to both transition to low-skill jobs and exit employment, and Hispanics are less likely to up-skill but no more or less likely to down-skill than whites. Finally, married individuals and workers with DB and DC pension coverage in their middle-skill job are less likely to experience any of the three transitions than singles and people who lack pensions.

In summary, the longitudinal analysis is less concerning than the cross-sectional result that middle-skill employment has decreased continuously for older workers, though not by as much as prime-aged workers - would suggest. At least until the Great Recession, the probability that a 50-61 year-old worker in a middle-skill occupation was exiting employment was actually

\footnotetext{
${ }^{12}$ The sum of the time trend and interaction terms is positive but just misses statistical significance at the 90 percent level.

${ }^{13}$ The results are similar using dummies for 2000-2007 and 2008-2013 (with 1990-1999 as the omitted condition). The coefficient on the two time-period dummies are positive and mostly statistically significant. In 2000-2007, the trend in up-skilling for older workers is positive and statistically significant, and the trend in exiting employment is statistically significant, but the trend in down-skilling is small and insignificant. None of the interaction effects is statistically significant for the 2008-2013 period, so the results discussed above are mostly due to the early- to mid2000s rather than more recent years.
} 
falling and the probability of finding a new job in a higher-skill occupation was increasing. And although more workers were moving to a low-skill job, fewer than half do so after an involuntary change, and many of these transitions are associated with a perhaps-deliberate reduction in hours.

\section{Skill-Level Transitions and Changes in Earnings}

Although older workers appear to be finding jobs even as middle-skill employment shrinks, lower earnings may still be associated with moving to a low-skill job, or even a job in a middle- or high-skill occupation that is less of a good fit. Figure 6 reports the average earnings gains or losses between $t-1$ and $t$, based on the worker's skill level in each year. ${ }^{14}$ Real monthly earnings for workers in middle-skill jobs in $t-1$ increase by an average of $\$ 92$ between $t-1$ and $t$ if they move to a high-skill occupation, compared to a minimal change (a loss of \$4 in real terms) by remaining at the middle-skill level. If they transition to a low-skill occupation instead, their real monthly earnings fall by $\$ 326$.

Transitions away from the other two skill levels are associated with larger earnings changes. Moving from a low-skill job to a middle-skill job increases real monthly earnings by \$322, and earnings increase by $\$ 640$ when low-skilled workers move up to high-skill occupations, which is rarer. Likewise, the loss from moving from high- to middle-skill - \$650 per month - is greater than the $\$ 92$ gain from going the other way, and high-skilled workers lose almost $\$ 938$ per month in the rare cases that they transition to a low-skill job. By comparison, middle-skilled workers who transition to another skill level have more modest earnings changes.

But workers who make these transitions differ in their personal characteristics in ways that may explain some of these earnings, so Table 6 presents estimates from a linear regression of the year-over-year earnings change among workers in middle-skill occupations in year $t-1$. The key independent variables are indicators for middle-to-high and middle-to-low occupation transitions. Because these transitions usually involve changing employers, we also include an indicator for middle-to-middle job transitions, and all three transitions are evaluated relative to the omitted condition of remaining with the same employer in the same job. The three transition

\footnotetext{
${ }^{14}$ We winsorize the data by excluding the top and bottom 2 percent of earnings changes. With the outliers included, the average earnings changes are \$282 for moving from middle to high skill, $\$ 12$ from remaining in middle, and a loss of $\$ 317$ for moving from middle to low.
} 
indicators are also interacted with a linear time trend. The regression also includes controls used in the previous regressions (results suppressed for space).

The first column of Table 6 features the results for workers ages 50-61. Relative to not changing jobs, middle-to-middle transitions are associated with a $\$ 190$ earnings gain, which is statistically significant at the 10 percent level. The gain is slightly higher when moving to a high-skill occupation, but the standard error is also larger so the estimate is not statistically distinct from zero, and is clearly not statistically significantly different from changing jobs within the middle-skill level. Middle-to-low earnings changes are also positive but insignificant. The time trends are all negative, suggesting that workers changing skill levels see smaller earnings changes in recent years, but each coefficient is small and statistically insignificant.

Younger workers, in contrast, have a larger earnings gain from moving to high-skill that is statistically significantly different than both no job change and job changes within the middleskill level, but amounts to a gain of only about 7.5 percent above the average earnings level for this group. Down-skilling is associated with earnings losses, but the estimate is statistically insignificant. The slope of earnings changes is statistically significant and negative but does not vary by the type of transition.

These results suggest that the consequences of transitioning across skill levels are, at most, relatively modest for older workers. Prime-aged workers are a better match for expectations that up-skilling benefits workers and down-skilling hurts earnings, but the estimates are noisy or not particularly large.

\section{Conclusion}

The decline in employment among middle-skilled workers - seen both in the CPS data used in previous studies and in the SIPP data used in this cross-sectional analysis - raises concerns that workers in these occupations will have trouble finding jobs in either the high- or low-skill level and that their earnings are likely to take a hit. The concern is especially acute for older workers, whose human capital may be specific to their employer or occupation and not general enough to be broadly hirable. If older workers reluctantly accept lower-paying jobs or are forced out of employment altogether, their already-weakening prospects for retirement income may take another unfortunate hit. 
But the results in this paper suggest otherwise. The cross-sectional decline in middleskill employment has had only modest consequences for older workers. At least until the Great Recession, they were actually becoming more likely to find work in both high- and low-skill occupations, and their rate of exit from employment was falling. The Great Recession reversed some of these gains, but the results from the previous economic expansion suggest that older workers are just as likely as - or even more likely than - prime-aged workers to land on their feet. Moreover, only half of the transitions to a lower skill level or out of employment altogether are undertaken after an involuntary job loss, and some appear to reflect a preference for moving to a part-time schedule. Finally, earnings changes associated with skill-level transitions are modest for older workers, and the estimates for prime-aged workers are also not substantial.

If the decline in middle-skill employment continues, it is likely to put further stress on safety-net programs, including unemployment insurance, Social Security Disability Insurance, Supplemental Security Income, Medicaid, other sources of cash and in-kind assistance, and job training initiatives. At least so far, however, the shift away from middle-skill occupations has not had a disproportionately adverse effect on workers ages 50-61. Rather than exiting employment and making ends meet until Social Security retirement benefits are available, they have been increasingly able to find jobs with high- and low-skill levels. A strong safety net and programs that assist with job searches and training may still be important, but only because they serve vulnerable workers and job seekers of all ages, not just older workers leaving middle-skill occupations. 


\section{References}

Aaronson, Stephanie, Tomaz Cajner, Bruce Fallick, Felix Galbis-Reig, Christopher L. Smith, and William Wascher. 2014. "Labor Force Participation: Recent Developments and Future Prospects.” Finance and Economics Discussion Series Working Paper 2014-64. Washington, DC: U.S. Board of Governors of the Federal Reserve System.

Ai, Chunrong and Edward C. Norton. 2003. "Interaction Terms in Logit and Probit Models.” Economic Letters 80(1): 123-129.

Autor, David H. 2010. “The Polarization of Job Opportunities in the U.S. Labor Market: Implications for Employment and Earnings.” Working Paper. Washington, DC: Center for American Progress and the Hamilton Project.

Autor, David H. 2014. "Polanyi’s Paradox and the Shape of Employment Growth.” Working Paper 20485. Cambridge, MA: National Bureau of Economic Research.

Autor, David and David Dorn. 2009. “This Job is 'Getting Old’: Measuring Changes in Job Opportunities Using Occupational Age Structure.” American Economic Review Papers and Proceedings 99(2): 45-51.

Autor, David H. and David Dorn. 2013. "The Growth of Low-Skill Service Jobs and the Polarization of the US Labor Market.” American Economic Review 103(5): 1553-1597.

Autor, David H., Frank Levy, and Richard J. Murnane. 2003. "The Skill Content of Recent Technological Change: An Empirical Exploration.” Quarterly Journal of Economics 118(4): 1279-1333.

Autor, David H., Lawrence F. Katz, and Melissa S. Kearney. 2008. “Trends in U.S. Wage Inequality: Revising the Revisionists.” The Review of Economics and Statistics 90(2): 300-323.

Beaudry, Paul, David A. Green, and Benjamin M. Sand. 2013. "The Great Reversal in the Demand for Skill and Cognitive Tasks.” Working Paper 18901. Cambridge, MA: National Bureau of Economic Research.

Berman, Eli, John Bound, and Zvi Griliches. 1994. "Changes in the Demand for Skilled Labor within U.S. Manufacturing: Evidence from the Annual Survey of Manufacturers.” Quarterly Journal of Economics 109(2): 367-397.

Bluestone, Barry and Bennett Harrison. 1988. "The Growth of Low-Wage Employment: 196386.” American Economic Review Papers and Proceedings 78(2): 124-128.

Cortes, Guido Matias. 2014. "Where Have the Routine Workers Gone? A Study of Polarization Using Panel Data.” Discussion Paper EDP-1224. Manchester, UK: University of Manchester. 
Cortes, Guido Matias, Nir Jaimovich, Christopher J. Nekarda, and Henry E. Siu. 2014. "The Micro and Macro of Disappearing Routine Jobs: A Flows Approach.” Working Paper 20307. Cambridge, MA: National Bureau of Economic Research.

Evangelist, Michael. 2014. "The Low-Wage Recovery: Industry Employment and Wages Four Years into the Recovery.” Data Brief. New York, NY: National Employment Law Project.

Foote, Christopher L. and Richard W. Ryan. 2015. "Labor Market Polarization Over the Business Cycle.” Working Paper 21030. Cambridge, MA: National Bureau of Economic Research.

Goos, Maarten and Alan Manning. 2007. "Lousy and Lovely Jobs: The Rising Polarization of Employment in Britain.” Review of Economics and Statistics 89(1): 118-133.

Holzer, Harry J. and Robert I. Lerman. 2009. “The Future of Middle-Skill Jobs.” CCF Brief \#41. Washington, DC: Brookings Institution Center on Children and Families.

Jaimovich, Nir and Henry J. Siu. 2014. "The Trend is the Cycle: Job Polarization and Jobless Recoveries.” Working Paper 18334. Cambridge, MA: National Bureau of Economic Research.

Juhn, Chinhui. 1999. "Wage Inequality and Demand for Skill: Evidence from Five Decades.” Industrial and Labor Relations Review 52(3): 424-443.

Mishel, Larry, Heidi Shierholz, and John Schmitt. 2013. "Don’t Blame the Robots: Assessing the Job Polarization Explanation of Growing Wage Inequality.” Working Paper. Washington, DC: Economic Policy Institute and Center for Economic and Policy Research.

Munnell, Alicia H. 2015. “The Average Retirement Age: An Update.” Issue in Brief 15-4. Chestnut Hill, MA: Center for Retirement Research at Boston College.

Munnell, Alicia H. and Matthew S. Rutledge. 2013. "The Effects of the Great Recession on the Retirement Security of Older Workers.” Annals of the American Academy of Political and Social Science, 650(1): 124-142.

Rutledge, Matthew S., Christopher M. Gillis, and Anthony Webb. 2015. "Will the Average Retirement Age Continue to Increase?” Working Paper 2015-16. Chestnut Hill, MA: Center for Retirement Research at Boston College.

Smith, Christopher L. 2013. “The Dynamics of Labor Market Polarization.” Finance and Economics Discussion Series 2013-57. Washington, DC: Federal Reserve Board of Governors. 
Tuzeman, Didem and Jonathan L. Willis. 2013. "The Vanishing Middle: Job Polarization and Workers’ Response to the Decline in Middle-Skill Jobs.” Federal Reserve Bank of Kansas City Economic Review 2013(1): 5-32.

Valetta, Robert G. 1991. “Job Tenure and Joblessness of Displaced Workers.” Journal of Human Resources 26(4): 726-741.

Willis, Robert J. 2013. "The Cognitive Demands of Work and the Length of Working Life: The Case of Computerization.” Working Paper. Ann Arbor, MI: University of Michigan. 
Table 1. Sample Selection Criteria

\begin{tabular}{lc}
\hline Criterion & Remaining sample \\
\hline 1990-2008 SIPP panels & $9,646,782$ \\
Ages 35-61 & $6,140,222$ \\
Identifiable civilian occupation and not self-employed & $5,177,583$ \\
Reshaped to person-years & 548,404 \\
& \\
Middle-skill analysis sample & 128,400 \\
Middle-skill in previous year & \\
& \\
Earnings regression sample & 123,264 \\
Not in top or bottom 2 percent of earnings changes & \\
\hline
\end{tabular}

Source: Survey of Income and Program Participation, 1990-2008 panels.

Table 2. Skill-Level Categorization, by Occupation

\begin{tabular}{|c|c|c|c|c|c|}
\hline Skill level & Occupations & Workers & Share & College + & Avg. earnings \\
\hline \multirow[t]{8}{*}{ Low } & & 84,979 & $23.5 \%$ & $7.3 \%$ & $\$ 2,340.97$ \\
\hline & Less-skilled sales & 9,835 & 2.7 & & \\
\hline & Less-skilled administration & 11,400 & 3.2 & & \\
\hline & Personal care \& services & 12,705 & 3.5 & & \\
\hline & Less-skilled protective services & 2,932 & 0.8 & & \\
\hline & Food prep and custodial & 21,659 & 6.0 & & \\
\hline & Agriculture & 4,883 & 1.3 & & \\
\hline & Laborers & 21,565 & 6.0 & & \\
\hline \multirow[t]{7}{*}{ Middle } & & 148,552 & $41.1 \%$ & $14.4 \%$ & $3,678.70$ \\
\hline & Professional Sales & 23,639 & 6.5 & & \\
\hline & Skilled administration & 49,332 & 13.6 & & \\
\hline & Skilled protective services & 4,053 & 1.1 & & \\
\hline & Skilled personal services & 1,174 & 0.3 & & \\
\hline & Production and repair & 38,537 & 10.7 & & \\
\hline & Operators and fabricators & 31,817 & 8.8 & & \\
\hline \multirow[t]{4}{*}{ High } & & 128,185 & $35.4 \%$ & $60.5 \%$ & $5,757.47$ \\
\hline & Managers & 52,592 & 14.5 & & \\
\hline & Professionals & 60,689 & 16.8 & & \\
\hline & Technicians & 14,904 & 4.1 & & \\
\hline All workers & & 361,716 & $100 \%$ & & \\
\hline
\end{tabular}


Table 3a. Employer Changes for Middle-Skilled Workers, by Age

\begin{tabular}{|c|c|c|}
\hline & Ages 50-61 & Ages 35-49 \\
\hline Same occupation & $82.3 \%$ & $80.9 \%$ \\
\hline Same employer & 78.3 & 76.1 \\
\hline Different employer & 4.0 & 4.8 \\
\hline Different occupation & 11.2 & 14.9 \\
\hline Same employer & 3.2 & 4.5 \\
\hline Different employer & 8.1 & 10.4 \\
\hline Exit employment & 6.4 & 4.2 \\
\hline
\end{tabular}

Table 3b. Skill-Level and Occupational Changes for Middle-Skilled Workers, by Age

\begin{tabular}{lcc}
\hline & Ages 50-61 & Ages 35-49 \\
\hline Same occupation & $82.3 \%$ & $80.9 \%$ \\
& & \\
Different occupation & 11.2 & 14.9 \\
$\quad$ Skill-level change & 5.7 & 7.2 \\
No skill-level change & 5.5 & 7.7 \\
& & \\
Exit employment & 6.4 & 4.2 \\
\hline Source: Survey of Income and Program Participation, 1990-2008 panels.
\end{tabular}


Table 4. Circumstances Surrounding Skill Level Transitions for Middle-Skilled Workers, by Age

\begin{tabular}{lcc}
\hline & Ages 50-61 & Ages 35-49 \\
\hline Middle-skill $\rightarrow$ High-skill & & \\
Same employer & $28.3 \%$ & $36.0 \%$ \\
Different employer & 71.7 & 64.0 \\
Promotion - Same employer & $9.3 \%$ & $11.2 \%$ \\
Promotion - Different employer & 19.5 & 17.4 \\
No promotion & 71.2 & 71.3 \\
Voluntary & $62.6 \%$ & $61.8 \%$ \\
Involuntary & 37.4 & 38.2 \\
Full-time to part-time & $5.3 \%$ & $4.3 \%$ \\
Part-time to full-time & 4.6 & 5.7 \\
No schedule change & 90.1 & 90.0 \\
& & \\
Middle-skill $\rightarrow$ Low-skill & & \\
Same employer & $22.9 \%$ & $22.3 \%$ \\
Different employer & 77.1 & 77.7 \\
Voluntary & $50.9 \%$ & $56.1 \%$ \\
Involuntary & 49.1 & 43.9 \\
Full-time to part-time & $13.4 \%$ & $10.9 \%$ \\
Part-time to full-time & 6.2 & 6.0 \\
No schedule change & 80.4 & 83.1 \\
& & \\
Involuntary & $55.7 \%$ & $44.3 \%$ \\
Middle-skill $\rightarrow$ Non-employment & 45.5 & 57.4 \\
\hline Voluntary & & \\
\hline
\end{tabular}

Note: Areas between shadings add up to 100 percent of the workers who move from the middle-skill to the respective level.

Source: Survey of Income and Program Participation, 1990-2008 panels. 
Table 5. Multinomial Logit Regression Results for Workers in Middle-Skill Occupations Initially

\begin{tabular}{|c|c|c|c|}
\hline \multirow{2}{*}{ Mean transition probability } & Mid $\rightarrow$ Nonemp & Mid $\rightarrow$ Low & Mid $\rightarrow$ High \\
\hline & 0.032 & 0.029 & 0.031 \\
\hline \multirow[t]{2}{*}{ Age 50-61 (0/1) } & -0.0037 & 0.0004 & -0.0006 \\
\hline & $(0.0030)$ & $(0.0033)$ & $(0.0032)$ \\
\hline \multirow[t]{2}{*}{ Time trend } & -0.00007 & $0.00054 * * *$ & $0.00033 * *$ \\
\hline & $(0.00014)$ & $(0.00014)$ & $(0.00015)$ \\
\hline \multirow[t]{2}{*}{ Age 50-61 $\times$ time trend } & $-0.00037 *$ & $-0.00040 *$ & 0.00004 \\
\hline & $(0.00021)$ & $(0.00022)$ & $(0.00021)$ \\
\hline \multirow[t]{2}{*}{ Log earnings last year } & $-0.043 * * *$ & $-0.025 * * *$ & $0.006 * * *$ \\
\hline & $(0.001)$ & $(0.001)$ & $(0.002)$ \\
\hline \multirow[t]{2}{*}{ Months in occupation } & $0.000027 * * *$ & $-0.000040 * * *$ & $-0.000028 * * *$ \\
\hline & $(0.000006)$ & $(0.000007)$ & $(0.000007)$ \\
\hline \multirow{2}{*}{$\begin{array}{l}\text { Potential experience } \\
\text { (age - education - 6) }\end{array}$} & $0.00081 * * *$ & 0.00023 & -0.00022 \\
\hline & $(0.00024)$ & $(0.00024)$ & $(0.00025)$ \\
\hline \multirow[t]{2}{*}{ Less than high school } & -0.002 & $-0.006 * *$ & $-0.010 * * *$ \\
\hline & $(0.002)$ & $(0.002)$ & $(0.002)$ \\
\hline \multirow[t]{2}{*}{ Some college } & 0.002 & -0.001 & $0.012 * * *$ \\
\hline & $(0.002)$ & $(0.002)$ & $(0.002)$ \\
\hline \multirow[t]{2}{*}{ College graduate } & 0.004 & $-0.005 *$ & $0.048 * * *$ \\
\hline & $(0.003)$ & $(0.003)$ & $(0.004)$ \\
\hline \multirow[t]{2}{*}{ Female } & $-0.015 * * *$ & $-0.011 * * *$ & $0.009 * * *$ \\
\hline & $(0.002)$ & $(0.002)$ & $(0.002)$ \\
\hline \multirow[t]{2}{*}{ Black } & $0.010 * * *$ & $0.015 * * *$ & -0.001 \\
\hline & $(0.003)$ & $(0.003)$ & $(0.003)$ \\
\hline \multirow[t]{2}{*}{ Asian } & 0.005 & 0.002 & 0.002 \\
\hline & $(0.005)$ & $(0.005)$ & $(0.005)$ \\
\hline \multirow[t]{2}{*}{ Other race } & 0.007 & $-0.011 * * *$ & $-0.008 *$ \\
\hline & $(0.005)$ & $(0.004)$ & $(0.004)$ \\
\hline \multirow[t]{2}{*}{ Hispanic } & 0.001 & 0.002 & $-0.009 * * *$ \\
\hline & $(0.002)$ & $(0.003)$ & $(0.003)$ \\
\hline \multirow[t]{2}{*}{ Married } & $-0.038 * *$ & $-0.038 * *$ & -0.014 \\
\hline & $(0.015)$ & $(0.016)$ & $(0.014)$ \\
\hline \multirow[t]{2}{*}{ Number of kids } & -0.001 & $0.001 *$ & $0.002 * *$ \\
\hline & $(0.001)$ & $(0.001)$ & $(0.001)$ \\
\hline \multirow[t]{2}{*}{ Spouse's age } & 0.000 & 0.000 & 0.000 \\
\hline & $(0.000)$ & $(0.000)$ & $(0.000)$ \\
\hline \multirow[t]{2}{*}{ Homeowner } & $-0.005 *$ & -0.003 & -0.005 \\
\hline & $(0.003)$ & $(0.003)$ & $(0.003)$ \\
\hline \multirow[t]{2}{*}{ Employer health insurance last year } & $0.015 * * *$ & -0.001 & -0.002 \\
\hline & $(0.002)$ & $(0.002)$ & $(0.002)$ \\
\hline
\end{tabular}

(cont'd) 
Table 5. Multinomial Logit Regression Results for Workers in Middle-Skill Occupations Initially (cont'd)

\begin{tabular}{lccc}
\hline \multirow{2}{*}{ Mean transition probability } & Mid $\rightarrow$ Nonemp & Mid $\rightarrow$ Low & Mid $\rightarrow$ High \\
\cline { 2 - 4 } & 0.000 & 0.000 & 0.000 \\
\hline DB pension last year & $-0.019^{* * *}$ & $-0.014^{* * *}$ & $-0.011^{* * *}$ \\
DC pension last year & $(0.002)$ & $(0.002)$ & $(0.002)$ \\
& $-0.018^{* * *}$ & $-0.011^{* * *}$ & $-0.009^{* * *}$ \\
& $(0.002)$ & $(0.002)$ & $(0.002)$
\end{tabular}

Family income relative to the poverty line

$\begin{array}{lccc}0-100 \text { percent } & -0.009^{* *} & -0.010^{* *} & -0.009 \\ & (0.005) & (0.005) & (0.011) \\ 100-200 \text { percent } & -0.001 & 0.002 & -0.009^{* *} \\ & (0.003) & (0.004) & (0.004) \\ 200-300 \text { percent } & -0.002 & -0.001 & -0.003 \\ 300-400 \text { percent } & (0.002) & (0.003) & (0.003) \\ & -0.003 & -0.001 & -0.006^{* * *} \\ & (0.002) & (0.002) & (0.002)\end{array}$

Net worth

\begin{tabular}{clcc} 
Lowest quintile & $-0.005^{*}$ & $0.009^{* *}$ & $-0.007^{* *}$ \\
2nd quintile & $(0.003)$ & $(0.004)$ & $(0.003)$ \\
& $-0.009^{* * *}$ & 0.001 & -0.004 \\
3rd quintile & $(0.002)$ & $(0.003)$ & $(0.002)$ \\
& $-0.007^{* * *}$ & -0.001 & -0.003 \\
4th quintile & $(0.002)$ & $(0.003)$ & $(0.002)$ \\
& $-0.005^{* *}$ & -0.001 & -0.002 \\
\hline Sample size & $(0.002)$ & $(0.003)$ & $(0.002)$ \\
\hline
\end{tabular}

Notes: The base outcome is that the worker remains in the middle-skill level. ${ }^{*} \mathrm{p}<0.05$; ${ }^{* *} \mathrm{p}<0.01 ;{ }^{* * *} \mathrm{p}<0.001$. Source: Survey of Income and Program Participation, 1990-2008 panels. 
Table 6. Results of Regression of Change in Earnings on Skill Level

\begin{tabular}{lcc}
\hline & Ages 50-61 & Ages 35-49 \\
\hline Middle to low & 156.51 & -114.74 \\
& $(187.19)$ & $(139.59)$ \\
Middle to middle & $190.29^{*}$ & 38.84 \\
& $(106.67)$ & $(72.69)$ \\
Middle to high & 310.30 & $381.46^{* * *}$ \\
& $(211.60)$ & $(130.48)$ \\
Time trend & -2.25 & $-4.49 * *$ \\
& $(2.57)$ & $(2.25)$ \\
Mid-low $\times$ time trend & -16.76 & -5.76 \\
& $(13.35)$ & $(10.78)$ \\
Mid-mid $\times$ time trend & -8.06 & -5.46 \\
& $(7.45)$ & $(5.74)$ \\
Mid-high $\times$ time trend & -0.87 & -6.35 \\
& $(14.83)$ & $(10.44)$ \\
\hline Sample size & 25,745 & 36,605 \\
$\mathrm{R}^{2}$ & 0.021 & 0.016 \\
\hline
\end{tabular}

Note: Regression also includes same personal characteristics in Table 5. ${ }^{*} \mathrm{p}<0.05 ; * * \mathrm{p}<0.01 ; * * * \mathrm{p}<0.001$. Source: Survey of Income and Program Participation, 1990-2008 panels. 
Figure 1. Employment Growth, by Skill Level and Age

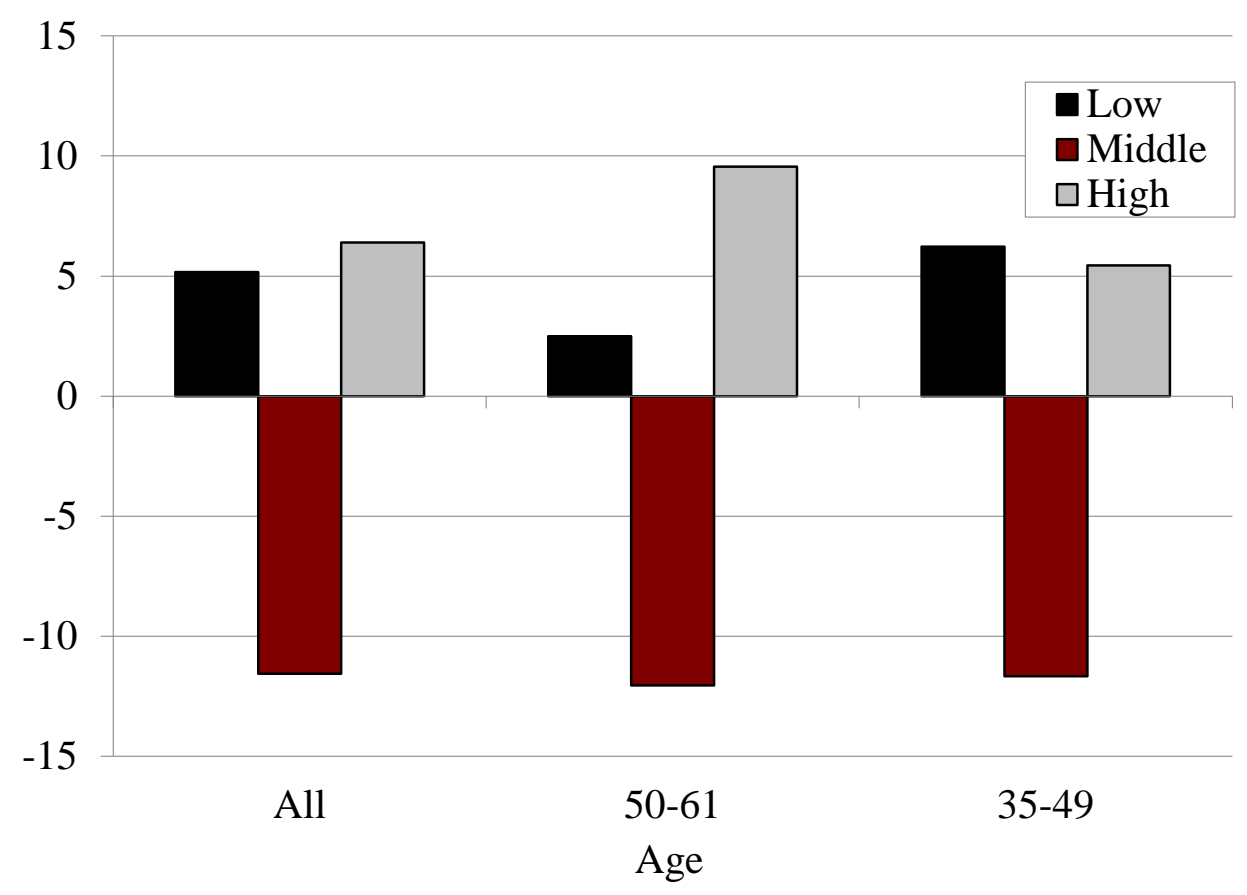

Source: Survey of Income and Program Participation, 1990-2008 panels.

Figure 2. Employment Growth, by Skill Level, Age, and Gender

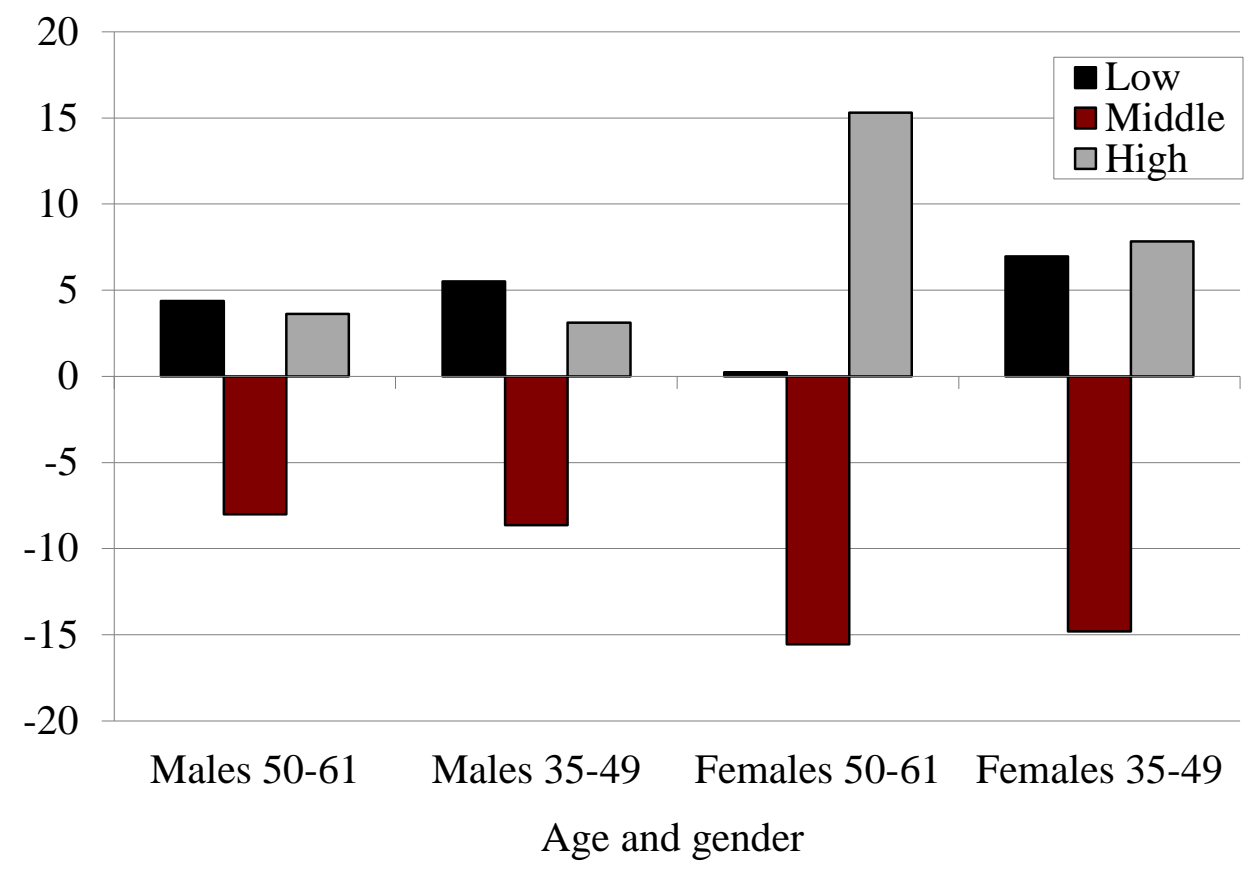

Source: Survey of Income and Program Participation, 1990-2008 panels. 
Figure 3a. Employment Growth at Ages 50-61, by Skill Level and Time Period

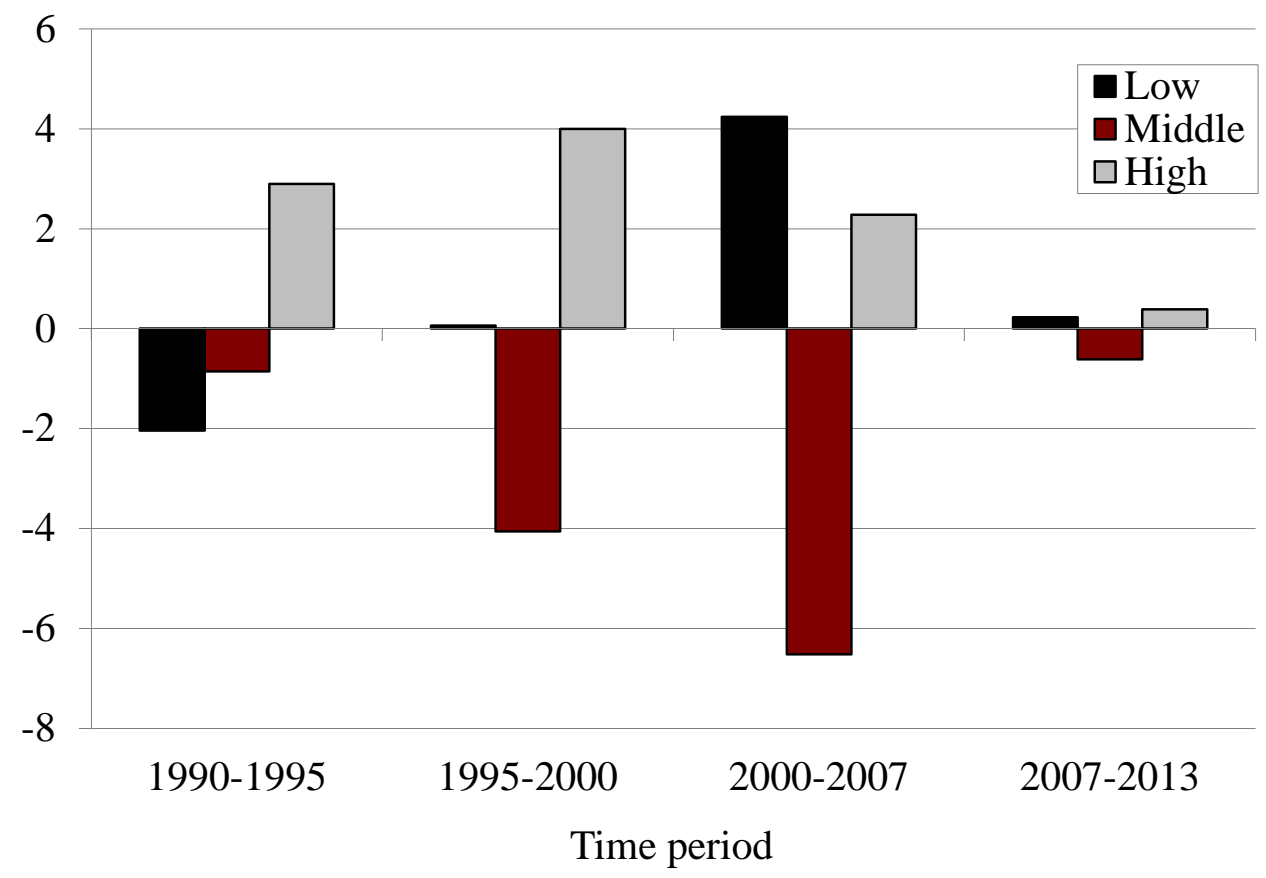

Source: Survey of Income and Program Participation, 1990-2008 panels.

Figure 3b. Employment Growth at Ages 35-49, by Skill Level and Time Period



Source: Survey of Income and Program Participation, 1990-2008 panels. 
Figure 4. Transition Probabilities, by Skill Level and Age

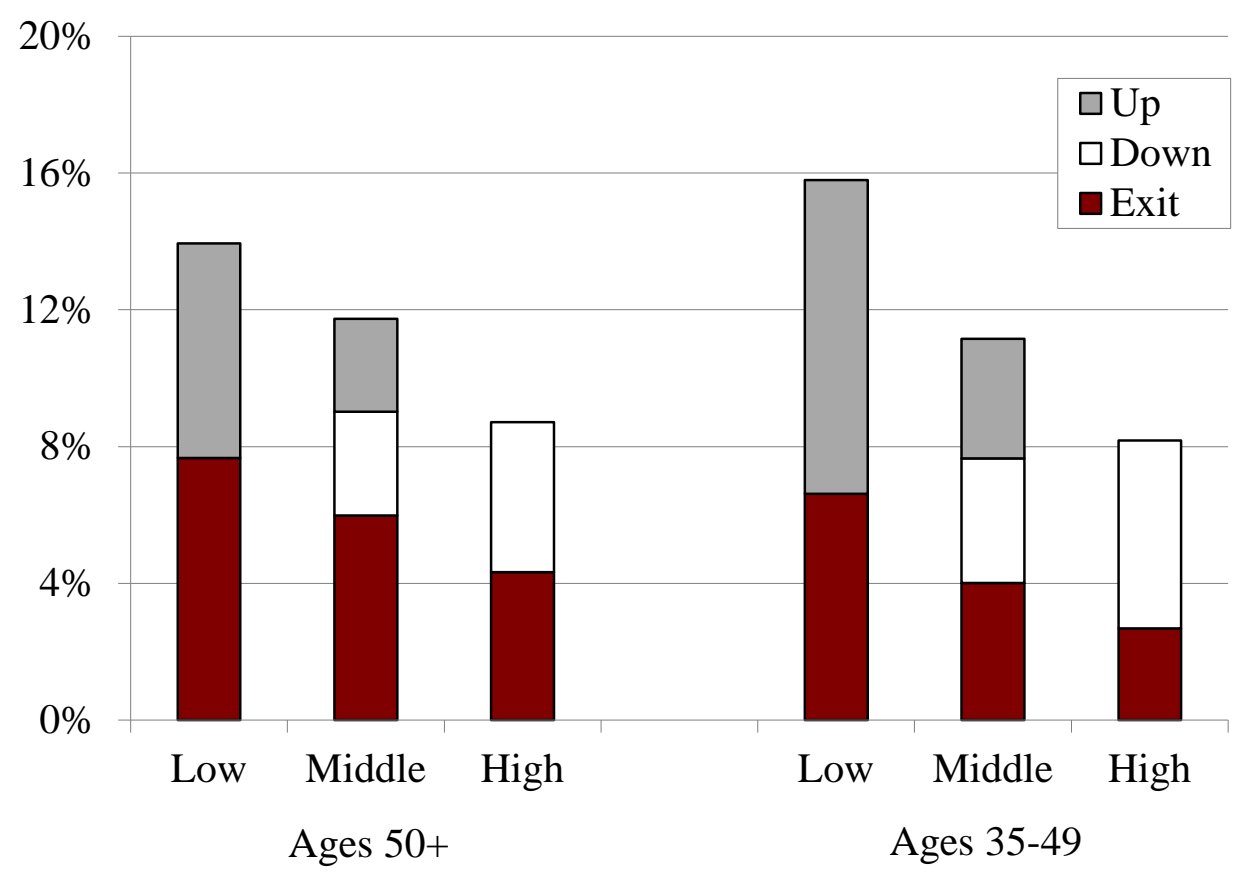

Source: Survey of Income and Program Participation, 1990-2008 panels.

Figure 5. Middle-Skill Transition by Panel among the Older Cohort

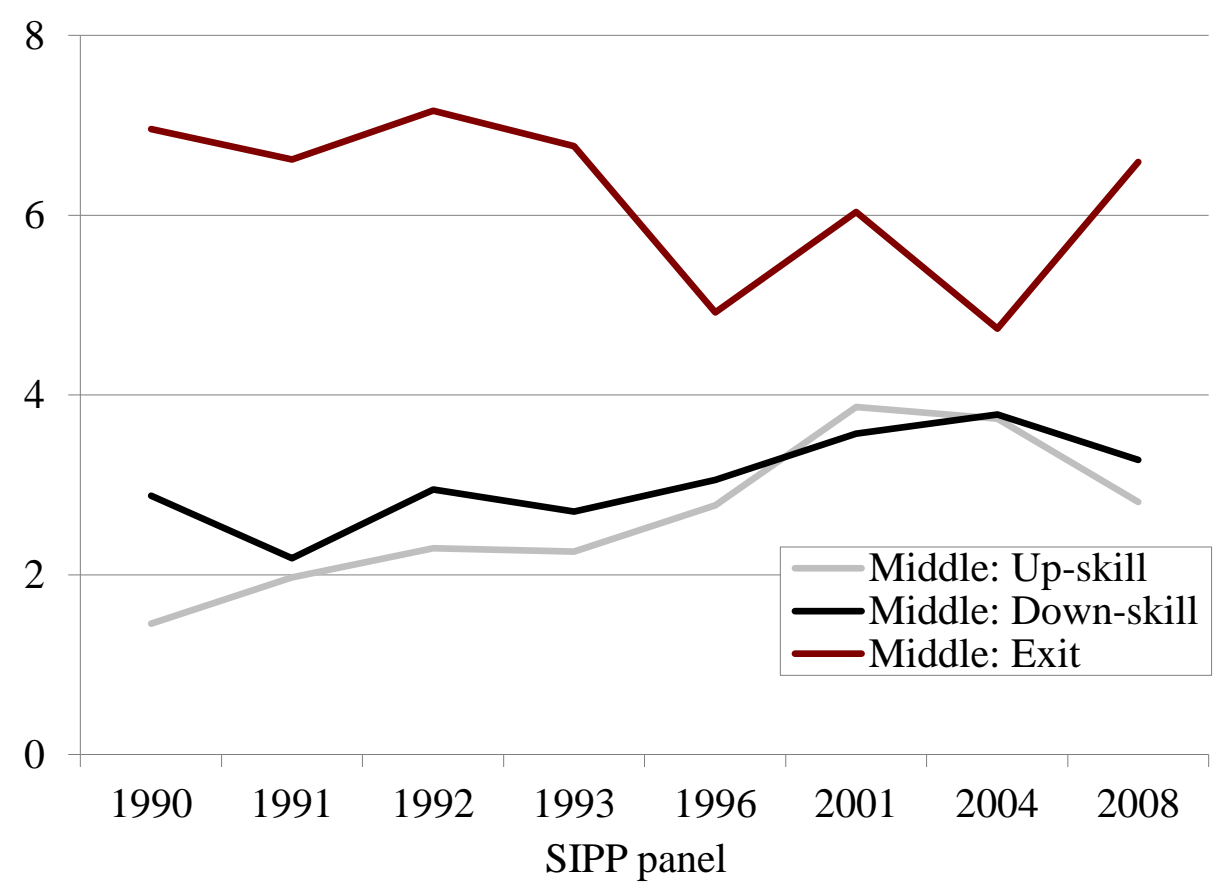

Source: Survey of Income and Program Participation, 1990-2008 panels. 
Figure 6. Change in Earnings, by This Year's and Last Year's Skill Levels

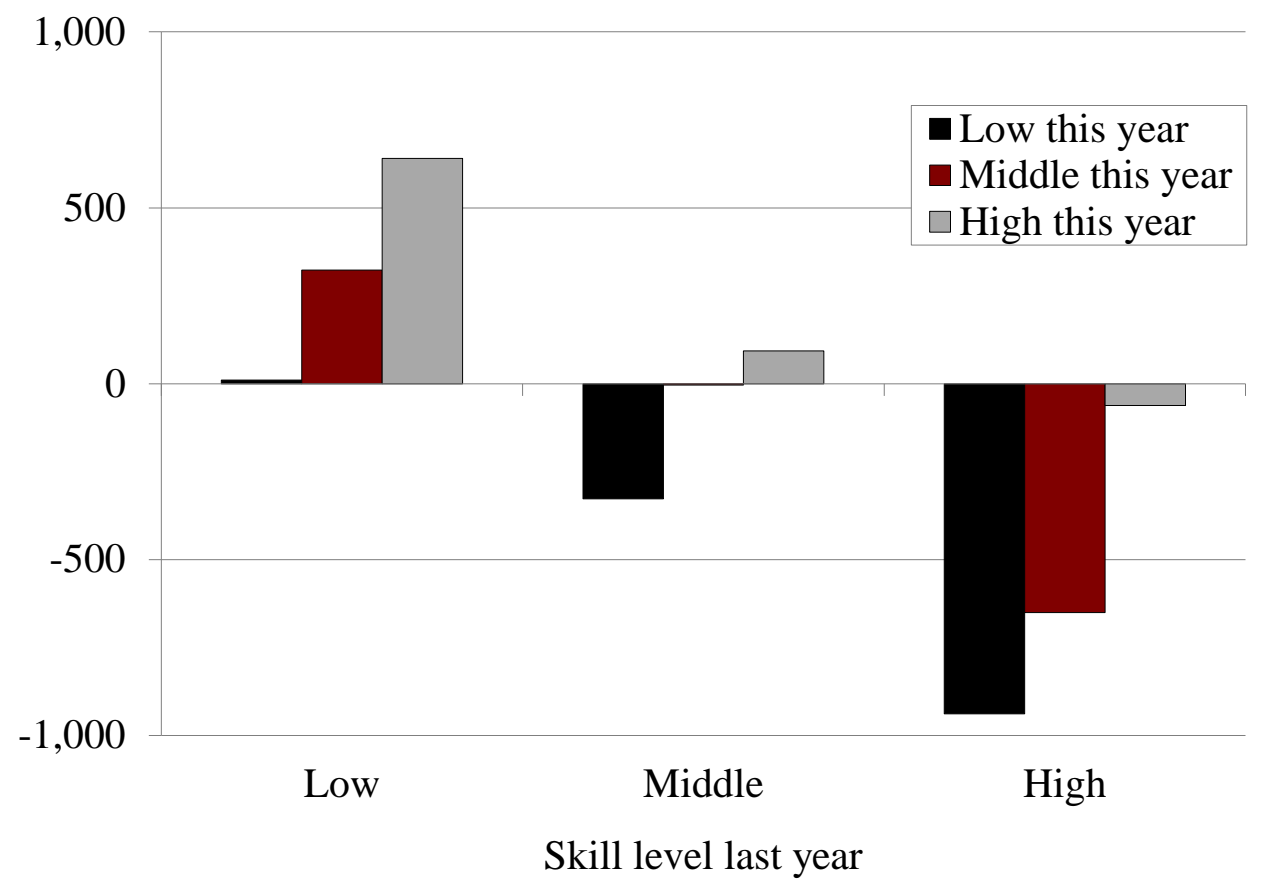

Source: Survey of Income and Program Participation, 1990-2008 panels. 
Table A1. Summary Statistics for Middle-Skilled Workers, by Skill Level Destination

\begin{tabular}{|c|c|c|c|c|}
\hline & Mid $\rightarrow$ Mid & Mid $\rightarrow$ Nonemp & Mid $\rightarrow$ Low & Mid $\rightarrow$ High \\
\hline \multirow[t]{2}{*}{ Age } & 47.6 & $49.2 * * *$ & $46.8 * * *$ & $46.6 * * *$ \\
\hline & $(6.8)$ & $(7.4)$ & $(6.7)$ & $(6.6)$ \\
\hline \multirow[t]{2}{*}{ Job transitions in year } & 0.1 & $1.1 * * *$ & $1.3 * * *$ & $1.2 * * *$ \\
\hline & $(0.4)$ & $(0.4)$ & $(0.5)$ & $(0.5)$ \\
\hline \multirow[t]{2}{*}{ Earnings } & $\$ 4,037.2$ & $\$ 0.1 * * *$ & $\$ 2,604.0 * * *$ & $\$ 5,029.7 * * *$ \\
\hline & $(\$ 3,236.4)$ & $(\$ 6.2)$ & $\$(2,490.3)$ & $(\$ 4,801.3)$ \\
\hline \multirow[t]{2}{*}{ Change in earnings } & $\$ 38.5$ & $-\$ 2,900.0 * * *$ & $-\$ 279.6 * * *$ & $\$ 418.8 * * *$ \\
\hline & $(\$ 2,545.6)$ & $(\$ 3,344.1)$ & $(\$ 2,631.0)$ & $(\$ 4,553.1)$ \\
\hline \multirow[t]{2}{*}{ Hours worked } & 40.3 & $0 * * *$ & $37.1 * * *$ & $40.6 * * *$ \\
\hline & $(8.6)$ & $(0)$ & (11.4) & $(10.7)$ \\
\hline \multirow[t]{2}{*}{ Months in occupation } & 174.4 & $167.8 * * *$ & $137.3^{* * *}$ & $156.9 * * *$ \\
\hline & $(114.7)$ & $(128.4)$ & (112.8) & $(110.2)$ \\
\hline Potential experience & 28.5 & $30.5 * * *$ & $28.1^{* * *}$ & $26.2 * * *$ \\
\hline (age - education - 6) & $(7.2)$ & $(7.7)$ & $(7.0)$ & $(7.0)$ \\
\hline \multirow[t]{2}{*}{ Less than high school } & 0.105 & $0.166^{* * *}$ & $0.148 * * *$ & $0.030 * * *$ \\
\hline & $(0.307)$ & $(0.372)$ & $(0.355)$ & $(0.171)$ \\
\hline \multirow[t]{2}{*}{ High school graduate only } & 0.377 & $0.389 * *$ & $0.406 * * *$ & $0.232 * * *$ \\
\hline & $(0.485)$ & $(0.487)$ & $(0.491)$ & $(0.422)$ \\
\hline \multirow[t]{2}{*}{ Some college } & 0.373 & $0.336 * * *$ & $0.349 * * *$ & $0.390 * *$ \\
\hline & $(0.484)$ & $(0.472)$ & $(0.477)$ & $(0.488)$ \\
\hline \multirow[t]{2}{*}{ College graduate } & 0.145 & $0.110 * * *$ & $0.097 * * *$ & $0.347 * * *$ \\
\hline & $(0.352)$ & $(0.312)$ & $(0.296)$ & $(0.476)$ \\
\hline \multirow[t]{2}{*}{ Female } & 0.447 & $0.536 * * *$ & $0.492 * * *$ & $0.521 * * *$ \\
\hline & $(0.497)$ & $(0.499)$ & $(0.500)$ & $(0.500)$ \\
\hline \multirow{2}{*}{ White } & 0.853 & $0.810 * * *$ & $0.788 * * *$ & 0.855 \\
\hline & $(0.354)$ & $(0.393)$ & $(0.408)$ & $(0.352)$ \\
\hline \multirow[t]{2}{*}{ Black } & 0.101 & $0.132 * * *$ & $0.162 * * *$ & $0.091 * * *$ \\
\hline & $(0.301)$ & $(0.339)$ & $(0.369)$ & $(0.288)$ \\
\hline \multirow[t]{2}{*}{ Asian } & 0.024 & $0.029 * *$ & 0.029 & 0.028 \\
\hline & $(0.155)$ & (0.169) & $(0.167)$ & $(0.166)$ \\
\hline \multirow[t]{2}{*}{ Other race } & 0.022 & $0.029 * * *$ & 0.021 & 0.025 \\
\hline & $(0.145)$ & $(0.167)$ & $(0.143)$ & $(0.157)$ \\
\hline \multirow[t]{2}{*}{ Hispanic } & 0.089 & $0.110 * * *$ & $0.126 * * *$ & $0.055 * * *$ \\
\hline & $(0.285)$ & $(0.313)$ & $(0.332)$ & $(0.227)$ \\
\hline \multirow[t]{2}{*}{ Married } & 0.720 & $0.678 * * *$ & $0.644 * * *$ & 0.724 \\
\hline & $(0.449)$ & $(0.467)$ & $(0.479)$ & $(0.447)$ \\
\hline \multirow[t]{2}{*}{ Number of kids } & 1.2 & $1.1^{* * *}$ & $1.3 * * *$ & $1.3 * * *$ \\
\hline & $(1.2)$ & $(1.2)$ & $(1.3)$ & $(1.2)$ \\
\hline \multirow[t]{2}{*}{ Homeowner } & 0.821 & $0.756 * * *$ & $0.716 * * *$ & $0.828 *$ \\
\hline & $(0.383)$ & $(0.429)$ & $(0.451)$ & $(0.377)$ \\
\hline
\end{tabular}

(cont'd) 
Table A1. Summary Statistics for Middle-Skill Workers, by Skill Level Destination

\begin{tabular}{ccccc}
\hline & Mid $\rightarrow$ Mid & Mid $\rightarrow$ Nonemp & Mid $\rightarrow$ Low & Mid $\rightarrow$ High \\
\hline Employer health insurance last year & 0.772 & $0.597^{* * *}$ & $0.619^{* * *}$ & 0.752 \\
& $(0.420)$ & $(0.491)$ & $(0.486)$ & $(0.432)$ \\
Family income relative to the poverty line & & & & \\
0-100 percent & 0.012 & $0.104^{* * *}$ & $0.050^{* * *}$ & $0.008^{* * *}$ \\
& $(0.107)$ & $(0.305)$ & $(0.218)$ & $(0.091)$ \\
100-200 percent & 0.058 & $0.176^{* * *}$ & $0.148^{* * *}$ & $0.041^{* * *}$ \\
& $(0.234)$ & $(0.381)$ & $(0.356)$ & $(0.198)$ \\
200-300 percent & 0.118 & $0.166^{* * *}$ & $0.185^{* * *}$ & $0.096^{* * *}$ \\
& $(0.323)$ & $(0.372)$ & $(0.388)$ & $(0.294)$ \\
300-400 percent & 0.150 & 0.146 & $0.164^{* *}$ & $0.123^{* * *}$ \\
& $(0.357)$ & $(0.354)$ & $(0.370)$ & $(0.328)$ \\
400 percent or more & 0.662 & $0.408^{* * *}$ & $0.453^{* * *}$ & $0.732^{* * *}$ \\
& $(0.473)$ & $(0.491)$ & $(0.498)$ & $(0.443)$ \\
Net worth & & & \\
Lowest quintile & 0.160 & $0.232^{* * *}$ & $0.279^{* * *}$ & $0.141^{* * *}$ \\
& $(0.367)$ & $(0.422)$ & $(0.449)$ & $(0.348)$ \\
2nd quintile & 0.224 & $0.213^{*}$ & $0.250^{* * *}$ & $0.194^{* * *}$ \\
& $(0.417)$ & $(0.410)$ & $(0.433)$ & $(0.395)$ \\
3rd quintile & 0.233 & $0.200^{* * *}$ & $0.206^{* * *}$ & $0.210^{* * *}$ \\
& $(0.423)$ & $(0.400)$ & $(0.404)$ & $(0.407)$ \\
4th quintile & 0.217 & $0.191^{* * *}$ & $0.157^{* * *}$ & $0.237^{* * *}$ \\
& $(0.412)$ & $(0.393)$ & $(0.364)$ & $(0.425)$ \\
Highest quintile & 0.165 & 0.164 & $0.108^{* * *}$ & $0.218^{* * *}$ \\
& $(0.371)$ & $(0.371)$ & $(0.310)$ & $(0.413)$ \\
\hline Sample size & 113,734 & 6,146 & 4,381 & 4,114 \\
\hline
\end{tabular}

Note: Asterisks denote statistically significantly different from Mid $\rightarrow$ Mid column: ${ }^{*} \mathrm{p}<0.05$; ${ }^{* *} \mathrm{p}<0.01$; ${ }^{* * *}$ $\mathrm{p}<0.001$.

Source: Survey of Income and Program Participation, 1990-2008 panels. 


\section{RECENT WORKING PAPERS FROM THE CENTER FOR RETIREMENT RESEARCH AT BOSTON COLLEGE}

What Causes Workers to Retire Before They Plan?

Alicia H. Munnell, Geoffrey T. Sanzenbacher, and Matthew S. Rutledge, September 2015

Calculating Neutral Increases in Retirement Age by Socioeconomic Status

Geoffrey T. Sanzenbacher, Anthony Webb, Candace M. Cosgrove, and Natalia S. Orlova, August 2015

How Does Occupational Access for Older Workers Differ by Education?

Matthew S. Rutledge, Steven A. Sass, and Jorge D. Ramos-Mercado, August 2015

How Much Longer Do People Need to Work?

Alicia H. Munnell, Anthony Webb, and Anqi Chen, August 2015

The Challenge of Pension Reform in Georgia: Non-Contributory Pensions and Elderly Poverty

Tamila Nutsubidze and Khatuna Nutsubidze, July 2015

The Transition from Defined Benefit to Defined Contribution Pensions: Does It Influence Elderly Poverty?

Natalia S. Orlova, Matthew S. Rutledge, and April Yanyuan Wu, July 2015

Will the Average Retirement Age Continue to Increase?

Matthew S. Rutledge, Christopher M. Gillis, and Anthony Webb, July 2015

The Role of Occupations in Differentiating Health Trajectories in Later Life

Michal Engelman and Heide Jackson, University of Wisconsin-Madison, July 2015

The Relationship Between Automatic Enrollment and DC Plan Contributions: Evidence from a National Survey of Older Workers

Barbara A. Butrica and Nadia S. Karamcheva, July 2015

Evidence of Increasing Differential Mortality: A Comparison of the HRS and SIPP Barry P. Bosworth and Kan Zhang, July 2015

Slowed or Sidelined? The Effect of “Normal” Cognitive Decline on Job Performance Among the Elderly

Anek Belbase, Mashfiqur R. Khan, Alicia H. Munnell, and Anthony Webb, June 2015

Does Social Security Continue to Favor Couples?

Nadia S. Karamcheva, April Yanyuan Wu, and Alicia H. Munnell, June 2015

All working papers are available on the Center for Retirement Research website (http://crr.bc.edu) and can be requested by e-mail (crr@bc.edu) or phone (617-552-1762). 